\title{
VERTICAL INTEGRATION IN ALUMINUM: A BAR TO "EFFECTIVE COMPETITION"
}

Tex Alcoa ${ }^{1}$ and American Tobacco ${ }^{2}$ decisions in the midforties sounded the bell for a new round in the fight against monopoly power. ${ }^{3}$ Power to control price and exclude competitors, whether held by one firm or several firms in combination, ${ }^{4}$ became the crux of the offense of monopolizing under Section 2 of the Sherman Act. The power alone-apart from its exercisewas condemned. And judicial definition of monopolization, emphasizing the existence of market power rather than the means by which it was acquired, ${ }^{5}$ at last began to jibe with the views of economists. ${ }^{6}$

But these doctrinal advances have produced new remedial problems. ${ }^{7}$ Where in the past specific illegalities could be directly struck down, cracking

1. United States v. Aluminum Co. of America, 148 F.2d 416 (2d Cir. 1945); see Note, 54 YALE L.J. 860 (1945).

2. American Tobacco Co. v. United States, 328 U.S. 781 (1946).

3. For analysis of the role these cases play in the growth of antitrust doctrine and the new possibilities for action under the Sherman Act which they portend, see two articles by Rostow: The New Sherman Act; A Positive Instrument of Progress, 14 U. OF CHr. L. Rev. 567 (1947); Monopoly Under the Sherman Act: Power or Purpose?, 43 ILL. 745, 761-778 (1949). See also Levi, The Antitrust Laws and Monopoly, 14 U. of Crr. L. Rev. 154, 174183 (1947). But of. Johnston \& Stevens, Monopoly or Monopolization-A Reply to Prof. Rostow, 44 ILL. L. REv. 269, 284-287 (1949) for a narrower view of the "new" Sherman Act's potentialities.

4. See American Tobacco Co. v. United States, 328 U.S. 781, 811 (1946); United States v. Patten, 187 Fed. 664, 672 (S.D. N.Y. 1911). The Tobacco case involved a fairly clear case of conspiracy between the firms controlling the market. For this reason the decision left unanswered the question of how much evidence is necessary to prove combination in a Section 2 case. See Rostow, Monopoly Under the Sherman Act: Power or Purpose? 43 ILL. L. Rev. 745, 781 (1949). Cf. Johnston \& Stevens, Monopoly or Monopolization-A Reply to Prof. Rostow, 44 Ill. L. Rev. 269, 283-6 (1949).

5. Only if such power is "thrust upon" a defendant is its possession not violative of the Sherman Act, United States v. Aluminum Co. of America, 148 F.2d 416, 429 (2d Cir. 1945). Cf. United States v. Eastman Kodak Co., 226 Fed. 62, 79 (W.D. N.Y. 1915) (normality of growth named as the test of Sherman Act violation).

6. The growing similarity between definitions of monopoly applied by judges and by economists is analyzed in Mason, The Current Status of the Monopoly Problem in the United States, 62 Harv. L. Rev. 1265 (1949). Cf. Mason, Monopoly in Law and Economics, 47 YALE L.J. 34 (1937).

7. See Levi, supra note 3, at 182: "But if the Sherman Act is to be made effective . . . something must be done about the relief secured from the courts." As to just what that "something" should be, opinions vary. Some authors press for increased appropriations for research in the Antitrust Division of the Department of Justice. See Hamilton \& Till, ANTitrust in Acrion 23-6 (TNEC Monograph 16, 1940); Arnold, Antitrust Law, Past and Future, 7 LAw AND ConTEMr. ProB. 5, 9-10 (1940). Others favor taking the burden off both the courts and the Antitrust Division by expanding the Federal Trade Commission. The FTC could then make comprehensive industry-wide studies and concoct the remedies to be recommended by the government. See Comment, British Monopolies Act of 1948: A Contrast with American Policy and Practice, 59 YALE L.J. 899, 926 (1950). For analysis of a specific legislative proposal aimed at more effective enforcement, see testimony of 
market control and establishing effective competition now requires tampering with basic industry patterns. Though court action of varying degrees of finality has now been taken in all five of the "new" Sherman Act cases," it is not yet possible to evaluate the full impact of the new doctrine. But such hindsight is not required for appraisal of the 1950 Alcoa divestiture decision. ${ }^{9}$ For the court's failure to disturb the industrial structure in aluminum makes thwarting of "new" Sherman Act goals almost inevitable.

The 1950 Alcoa case came as a sequel to the 1945 decision, ${ }^{10}$ in which Alcoa's $90 \%$ share of domestic virgin ingot production was held to be a monopoly. ${ }^{11}$ In 1945 the Second Circuit chose to take no remedial action, preferring to wait till it could ascertain the effect on competition of Government disposal of its war-built aluminum plants. ${ }^{12}$ Subsequent sale of these paants to Reynolds and Kaiser ${ }^{13}$ revolutionized the industry, leaving Alcoa with control of only $50 \%$ of ingot capacity. ${ }^{14}$ On the strength of this develop-

Walton Hamilton, Hearings before the Subcammittee on Study of Monopoly Power of the House Committee on the Judiciary, 81st Cong., 1st Sess. 285-289 (1950).

But numerous aberrations must not obscure the substantial impact, direct and indirect, of administrative and judicial action under the antitrust laws. For an appraisal of their effect and a comparison with the British experience, see Comment, The British $\mathrm{Mro}$ nopolies Act of 1948: A Contrast with American Policy and Practice, 59 YALE L.J. 899, 921 (1950).

8. The five major "new" Sherman Act cases are listed in note 16 infra. In the Griffitz case, a recent District Court opinion refused divestiture, but granted an injunction prohibiting defendants from licensing films for their open and closed towns in single contracts. United States v. Griffith Amusement Co., No. 172-Civil (W.D. Okla., December 1950). It is not clear how great an effect this will have on the chain's bargaining position. See also United States v. Griffith Amusement Co., CCH Trade Rep. '48-'51, ๆ 62,582 (D. Okla. 1950) (denying a Government motion to join the lessee of certain theatres as party defendant). The American Tobacco case was a criminal case, and resulted in fines totalling $\$ 255,000$. The Schine case has been concluded by a consent decree, ordering disposition of some forty theatres, and enjoining certain practices. United States v. Schine Chain Theatres, Inc., CCH TRADE CASES II 62,447 (W.D. N.Y. 1949). For the Alcoa case, see text infra.

The most striking remedial action taken, however, is the divestiture decree in the Paramount case. 85 F. Supp. 881 (S.D. N.Y. 1949). For a competent analysis of the additional steps necessary to insure continuing competition in the motion picture industry, see McDonough \& Winslow, The Motion Picture Industry: United Stales v. Oligopoly. I STAN. L. REv. 385 (1949).

9. United States v. Aluminum Co. of America, 91 F. Supp. 333 (S.D. N.Y. 1950).

10. United States v. Aluminum Co. of America, 148 F.2d 416 (2d Cir. 1945).

11. Id. at 425 ; but note that what at first glance might appear to be a percentage test was preceded by a detailed market analysis in regard to the inclusion of "secondary aluminum."

12. Id. at 446-7. For the antitrust goals that were to guide surplus property disposal, see Sec. 2 of the Surplus Property Act, 58 Stat. 765 (1944), 50 U.S.C. Apr. $§ \S 1611,1627$, 1629 (Supp. 1945).

13. For description of this disposal process, see Stein, The Disposal of the Alumiinum Plants (Committee on Public Administration Cases, 1948); Report of the Surplus Property Board to the Congress (Sept. 21, 1945).

14. The 1950 court chose percentage of primary aluminum production as the yardstick of market control. United States v. Aluminum Co. of America, 91 F. Supp. 333, 363 (S.D. 
ment, Alcoa petitioned the District Court for a declaration that it no longer constituted a monopoly. The Government countered with a divestiture plan aimed at splitting Alcoa into two integrated competitors, ${ }^{15}$ and the issue was joined.

Because the structure of the aluminum industry had been so radically changed since the 2nd Circuits' 1945 decision, the District Court was faced with a troublesome doctrinal dilemma. It was by no means clear that even the broadest version of the "new" test would hold Alcoa to be presently in violation of Section 2. ${ }^{16}$ But the District Court's narrow view of that test

N.Y. 1950). The Government, in is brief at p. 98, claimed "that the production yardstick is susceptible to manipulation, and is not a reliable measure of market control in this industry." To back up this contention, it cited the testimony of Mr. Wilson, a Vice-President of Alcoa, Transcript of Record, p. 974, to the effect that Alcoa had to keep on its toes to keep from producing more than $50 \%$ of primary aluminum. The Gover iment Brief further suggested that "The most meaningful measure of market control in this industry is metal controlled, i.e., the primary aluminum produced and acquired by Alcoa, Reynolds and Kaiser . . . for it reflects the full potential of each producer to penetrate the market." Brief at 98 . The metal-controlled test would boost Alcoa's share up to an average of $57.4 \%$ for the three and three-quarter year period involved. See id. table 7 .

15. In November 1948, before submitting its divestiture plan, the United States sought a writ of mandamus directing the district court to strike from Article XII of the 1945 judgment "a clause which gives leave to 'Alcoa' to apply to the district court 'for a determination of the question whether or not it still has a monopoly in the ingot market." "United States v. District Court for the Southern District of New York, 171 F.2d 285 (2d Cir. 1948). In denying the Government's petition the Second Circuit emphasized that "[d]issolution . . . will not depend on the single question whether 'Alcoa' at the time of the judgment shall have a monopoly of the ingot market. On the contrary, it will depend upon what is 'Alcoa's' position in the industry at that time." Id. at 286.

The Government's divestiture plan, set out in the Supplement to the Brief of the United States at 5-16, involved setting up a competitor with both production and fabrication facilities. The new competitor would produce about $10 \%$ of primary aluminum at costs comparable to Alcoa's.

16. The principal cases under the "new" Sherman Act are United States v. Paramount Pictures, Inc., 334 U.S. 131 (1948); Schine Chain Theatres v. United States, 334 U.S. 110 (1948); United States v. Griffith Amusement Co., 334 U.S. 100 (1948); American Tobacco Co. v. United States, 328 U.S. 781 (1946); and United States v. Aluminum Co. of America, 148 F.2d 416 (2d Cir. 1945). These cases constitute a striking departure from earlier cases, typified by United States v. United States Steel Corp., 251 U.S. 417 (1920), which emphasized the methods by which market power was utilized rather than the existence of the power. Under their broadest interpretation, the new cases stand for the proposition that it is unlawful under Section 2 of the Sherman Act, for one firm or a combination of firms, to acquire, in the course of making normal business decisions, sufficient market dominance to be able "substantially to influence" the price structure in the market, or to restrict free entry into the market. See Rostow, Monopoly under the Sherman Act: Power or Purpose?, 43 ILL. L. REv. 745, 763 (1948). Even under the new test, thus interpreted, the following considerations make it unclear whether, without substantial extension of present doctrine, the court could have found a present Section 2 violation on the part of Alcoa.

(1). The position of Alcoa alone. This involves the two problems of whether Alcoa holds present monopoly power, and whether it has monopolized. (a) The U.S. Steel decision, supra, found no violation in an industrial structure closely paralleling that of the present aluminum industry. The decision emphasized the fact that U.S. Steel's percentage share of 
removed all doubts; no present violation could have been found. The "new" Sherman test began with percentage size based on a full analysis of market structure, and then proceeded to analyze the power over price and entry accompanying that size. ${ }^{17}$ Though the court did not apply any Section

the market totalled only $51 \%$. It also emphasized recent decreases in that percentage share. Alcoa may now have in some respects greater influence in the aluminum industry than U.S. Steel did then in the steel industry. But, even assuming that that greater degree of power would be uncovered by the thorough market analysis required by "new" Sherman Act doctrine, the situations presented in the two cases are sufficiently similar that a finding of present violation on the part of Alcoa would necessarily require effective overruling of the Steel case. Furthermore, assuming that that could be done in view of the impact of the "new" Sherman Act cases, it is not clear that the court could have found present domination by Alcoa sufficient to give it power substantially to influence price. The actual findings made indicate the opposite: "In themselves, under present market conditions, [the superiority of Alcoa's physical resources does] not bar effective competition." 91 F. Supp. 333, 380 (S.D. N.Y. 1950). See also id. at 365 (price domination not established); id. at 392 (Alcoa's patent position not a threat to effective competition); note 26 infra. The inadequacy of some of the court's analysis, particularly that portion dealing with the price structure, however, and the bypassing of the problem of vertical integration, makes it unclear whether a different court would have been forced to the same conclusions. (b) A finding that the possessor of monopoly power has "monopolized" within the meaning of Section 2 of the Sherman Act requires a showing that the defendant has deliberately obtained or maintained the requisite power. Aluminum Co. of America v. United States, 148 F.2d 416, 429-32 (2d Cir. 1945). The deliberateness means nothing more than that the power must have resulted from a course of business practice, in itself perfectly lawful, rather than happenstance. In the instant case, the making of such a finding would be hampered by the fact that whatever Alcoa's business policies have been over the past five years, its percentage share of the market decreased from 90 to $50 \%$. Furthermore, Alcoa has been consistently under the jurisdiction of the court for over ten years, and has been existing under the threat of dissolution for five--factors which are not conducive to any policy directed towards either obtaining more power, or even maintaining the degree of power already found to be a violation. For the court's discussion of these points, see 91 F.Supp. at 402-16.

(2). The industry as a whole. Whether or not Alcoa alone occupies such a dominant position in the industry as to be itself in violation of Section 2, it seems clear that the structure of the industry as a whole precludes the entry of new competitors. See pages 301-05 infra. The court so found. $91 \mathrm{~F}$. Supp. 331, 401. The power to exclude competitors constitutes a Section 2 violation. American Tobacco Co. v. United States, supra. But if that power is held by the whole industry, rather than by one firm in it alone, an essential element in the violation is the finding of a combination or conspiracy to acquire or maintain such power. Since no combination or conspiracy was alleged or argued in the instant case, no evidence was presented and no findings could be made on this point. But it seems likely that any attempt to prove combination or conspiracy would necessarily rely mainly on (a) the mere existence of identical organization, i.e. vertical integration, on the part of Alcoa, Reynolds, and Kaiser, and (b) evidence of parailel response by all three to market stimuli. It is doubtful that present doctrine goes that far. Compare the fact situations in United States v. Paramount Pictures, Inc., supra; FTC v. Cement Institute, 333 U.S. 683 (1948); American Tobacco Co. v. United States, supra. And see Clayton Mark \& Co. v. FTC, 168 F.2d 175 (7th Cir. 1948), affirmed by equally divided court, 336 U.S. 956 (1949), discussed in Johnson \& Stevens', supra note 3, at 293-4. Cf. Rostow, supra at 781-5 (economic fact of pooling of power enough for showing of combination).

17. See note 3 supra. See also United States v. Aluminium Co. of America, 148 F.2d 416, 430 (1945); United States v. American Tobacco Co., 328 U.S. 781, 809 (1946). 
2 test, it apparently took a more limited view of what the test was. Instead of being a factor relevant to the determination of market power, percentage share became the crux of the test; analysis of the power that comes with size in a given market was made superfluous. For purposes of this test, the crucial determinant would have been Alcoa's present 50\% share of domestic virgin ingot capacity. ${ }^{18}$ As Judge Knox read the unfortunate "30-60-90" dictum in the 1945 Alcoa case ${ }^{19}$ and the Supreme Court's opinion in the Columbia Steel case, ${ }^{20} 50 \%$ would be insufficient to constitute a violation. Thus if this court's monopoly test had been used as a test of the need for remedy, no monopoly would have been found and no remedial action possible.

Precluded from taking remedial action under its view of Section 2 standards, the court went on to fashion a special remedial test of its own. The court held that even if Alcoa did not have present monopoly power, remedial action must be taken if present market conditions did not preclude any "reasonable expectation of the resumption of future unlawful conditions." 21

18. See note 14 supra.

19. United States v. Aluminum Co. of America, 91 F. Supp. 333, 345 (S.D. N.Y. 1950). Judge Learned Hand's dictum in the 1945 Alcoa case stated that "[ $[90$ per cent] is enough to constitute a monopoly; it is doubtful whether sixty or sixty-four per cent would be enough; and certainly thirty-three per cent is not." United States v. Aluminum Co. of America, 148 F.2d 416, 424 (2d Cir. 1945).

Definition of monopoly in such percentage terms is sharply criticized in Mason, supra note 6 , at 1274 , and McDonough \& Winslow, supra note 8 , at 424 . The inconsistency of reliance on percentage short-cuts with the detailed market analysis that formed the basis of Judge Hand's opinion is commented on by Rostow in Monopoly Under the Sherman Act; Power or Purpose?, 43 ILI. L. REv. 745, 778 (1949) "Unfortunately, (percentage) ceilings ... . are not practicable. The significance of a given absolute size differs from case to case with variations in technology, in methods of economic organization, and in the size and strength of those with whom the large enterprise deals. . . . and in the ease with which new competition can appear." EDWARds, MatnTaIning Competirion 120-1 (1949).

20. The court read United States v. Columbia Steel Co., 334 U.S. 495 (1948), as depending largely on the fact that United States Steel controlled no more than $51 \%$ of the rolled steel and ingot capacity in the relevant market. United States v. Aluminum Co. of America, 91 F. Supp. 333, 345 (S.D. N.Y. 1950.) Cf. Mason, supra note 6, at 1265; Note, The Columbia Steel Case: New Light on Old Antitrust Problems, 58 YALE L.J. 764, 773 (1949), for a more plausible explanation of that court's rationale in terms of the estoppel element involved after United States Steel's purchase of the Geneva plant had been encouraged by the government.

The 1950 court's interpretation of the Columbia Steel case, coupled with reliance on the 1945 Alcoa dictum discussed in note 19 supra, gives rise to a strong implication that it would have considered a showing of $50 \%$ control or less an almost complete defense to a de novo charge of monopoly.

21. United States v. Aluminum Co. of America, 91 F. Supp. 333, 346 (S.D. N.Y. 1950).

Both the Brief of the United States, at p. 13, and the remedial mandate of the Circuit Court, United States v. Southern District of New York, 171 F.2d 285, 286 (2d Cir. 1948), point out that even though Alcoa may no longer have a monopoly in the ingot market, divestiture may still be in order. The implication was that though monopoly may have vanished from the ingot field, it could appear in other markets. The 1950 court, misreading these admonitions, reasoned "that competitive conditions, i.e. effective competition . . . 
When Alcoa was convicted in 1945, its intent to monopolize was presumed from its continuing efforts to maintain a dominant market position. ${ }^{22}$ In 1950 , though the monopoly stigma might have vanished, this constructive "intent" lingered on. Thus the court felt that something less than monopoly power, when tainted with the presumption of lingering "intent," would still make remedial action necessary. ${ }^{23}$ Only the present existence of "effective competition," strong enough to insure against monopoly power being "thrust upon" Alcoa in the foreseeable future, could save Alcoa from the judicial knife. ${ }^{24}$

The question, as the court saw it, was whether Alcoa's position barred "competitive conditions" in the aluminum industry. ${ }^{25}$ The court concluded that it wasn't quite sure. ${ }^{26}$ On the one hand it feared that Reynolds and Kaiser might be only hot-house competitors. On the other it felt that the needs of national defense made it hazardous to chance disruption and that Alcoa needed strength to compete with the other giants in the basic metal industries. Moreover, the court thought that the staying power of the new competitor proposed by the Government would be too speculative to promote "effective competition" in aluminum. ${ }^{27}$

But judicial innovation of the "effective competition" test was not without purpose; the court was quick to put its handiwork to use. Alcoa was tied to the principal Canadian producer, Aluminium Ltd., through partial

conforming to law ... may not exist even though the Sherman Act were not violated, because of Alcoa's stronger market position in relation to its competitors," United States v. Aluminum Co. of America, 91 F. Supp. 333, 340 (S.D. N.Y. 1950).

For an earlier hint at the "competitive conditions" test for remedial action, see United States v. United States Steel Corp., 251 U.S. 417, 465-6 (1920) (dissenting opinion).

22. United States v. Aluminum Co. of America, 148 F.2d 416, 432 (1945).

23. United States v. Aluminum Co. of America, 91 F. Supp. 333, 347 (S.D. N.Y. 1950). Cf. United States v. United States Steel Corp., 251 U.S. 417 (1920), where discarding, before suit was brought, of the practices tending to show intent to monopolize resulted in a finding of no violation.

Professor Eugene V. Rostow, of the Yale Law School, suggested in a recent speech that this "something less than monopoly power" may be a violation of Section 1 of the Sherman Act. Speech before the New York State Bar Association, January 24, 1951, mimeographed copy in Yale Law Library, at p. 17. The court made no clear reference to this possibility.

24. Id. at 346. The term "workable competition" first appeared in Clark, Toward a Concept of Workable Competition, 30 AN. EcoN. REv. 241, 243 (1940). As a goal for antitrust remedies, it was defined in terms of "a considerable number of firms selling closely related products in the same market ... . the absence of collusion, and a long run cost curve for each new firm not materially higher than that for an established firm." Stigler, The Extent and Bases of Monopoly, 32 Arr. Econ. Rev. 3 (Supp. June 1942). Edwards has added as a vital prerequisite for "workable competition" - the absence of a "dominant trader." Edwards Maintaining Competition 9-10 (1949).

25. Id. at 340 .

26. "[T]he evidence in this proceeding is insufficient to give me a well founded assurance that, in future years, competitive conditions of an effective and lawful nature will be certain to prevail." Id. at 416 (Emphasis added).

27. Id. at 416 . 
joint stock ownership. This relationship was deemed lawful by the 1945 court. The District Court here held that, despite present lawfulness, the tie-up placed the companies in a position to stunt the growth of Reynolds and Kaiser. Accordingly it ordered the joint stock owners to sell either their Alcoa or their Aluminium stock. ${ }^{28}$

Beyond this the court probed cautiously. Alcoa's productive capacity emerged untouched. Provisions in license contracts requiring the licensee to turn over to Alcoa all improvement patents he might develop were held unenforceable as potential restraints on future competition. ${ }^{29}$ And the court procrastinated, retaining jurisdiction for five more years to see how Reynolds and Kaiser fare.

To decide "whether competitive conditions prevailed"-i.e. whether the present structure portended future effective competition-the court had to analyze Alcoa's power in the national market. But the aluminum industry embraces many "markets." 30 Bauxite is mined and the silica removed to produce alumina. Alumina is reduced to aluminum, in pig and ingot form. Fabricators purchase pig and ingot and turn out finished aluminum products. Most fabrication, however, is not independently owned, but is integrated with ingot production. ${ }^{31}$ Although one-fourth of Alcoa's ingot production, and a substantially smaller portion of Reynolds' and Kaiser's, is diverted to independent fabricators, ${ }^{32}$ each of these producers owns fabricating capacity capable of consuming its total ingot production. ${ }^{33}$

From these several "markets" the court was to choose one or more for its analysis of "competitive conditions." The court noted that Alcoa, Reynolds, and Kaiser have preempted-via integration-a "captive market"

28. Id. at 392-9, 418. See Wall St. Journal, Jan. 17, 1951, p.6, col. 3.

29. Id. at 410. The court held these provisions unenforceable as a "potential restraint on the restoration of lawful competitive conditions." Cf. Transparent-Wrap Machine Corp. v. Stokes \& Smith Co., 329 U.S. 637 (1947) (similar grantback provisions held not illegal per se). See United States v. Aluminum Co. of America, 51 CoL. L. Rev. 238 (1951).

30. For a comprehensive study of the stages of production in the aluminum industry, see WALlace, Market Control in THe AluMinum Industry (1937) passim.

31. There is nowhere listed the total number of aluminum fabricating plants, integrated or independent, in the United States. However, the relative significance of the independents can be gauged by the number of tons of ingot they fabricate. In 1948, Alcoa, which supplied $86 \%$ of the ingot consumed by the non-integrated fabricators, sold $185,650,000 \mathrm{lbs}$. to the independents. That means that the total amount of ingot fabricated by the independents was about $218,411,000 \mathrm{lbs}$. In the same year, the total amount of primary ingot produced was $1,291,911,000$ lbs. Thus less than $171 / 2 \%$ of ingot produced was fabricated by independents. That, in turn, means that $82 \mathrm{~J} / 2 \%$ of all sales outlets for ingot were preempted via integration. See United States v. Aluminum Co. of America, 91 F. Supp. 333, 360 and Table III (S.D. N.Y. 1950). Substantially the same conclusion can be drawn from examination of comparable statistics for the first nine months of 1949.

32. This diversion of ingot, in 1948 , cost Alcoa an estimated $\$ 5,000,000$ in profits. Id. at 356 .

33. Id. at 356,372 . But note the difference in the diversification of the fabricating facilities of the three producers and the effect of such diversification on the comparative ability of each to prosper in hard times. Id. at $372,374,385$. See note 56 infra. 
for ingot, a market consisting of $82 \%$ of total ingot sales. ${ }^{34}$ Thus whatever competition exists is found in the market for fabricated products, not in sales of ingot. ${ }^{35}$ But little evidence was submitted on "competitive conditions" in the fabricated market. So, assuming the necessity for integration, the court generalized: in essence it considered all "markets" as one. ${ }^{36}$ All aluminum products, pig or ingot, fabricated or semi-fabricated, whether sold to independent or integrated fabricators, jobbers or ultimate consumers, were rolled into one "market" for the court's purposes.

Never questioned by either the court or the Government was the major premise of this market analysis - the necessity for integration of producers and fabricators. By ignoring the problem of integration, the court left unaltered an industrial structure which-if Reynolds and Kaiser surviveresembles the pattern of domination just condemned in the Paramount case. ${ }^{37}$ It overlooked the fact that integration of producers and fabricators blocks entrance into both markets. ${ }^{38}$

A new ingot producer would probably have to build his own fabrication plants. For so long as the integrated fabricators continue to operate at $50 \%$ capacity, a newcomer faces a market for ingot which is over $82 \%$ closed to him. ${ }^{39}$ Even without the added hurdle of a restricted market, entrance

34. Id. at 356. See note 31 supra.

35. The court recognized this fact. Id. at 356 .

36. Id. at 357 .

37. United States v. Paramount Pictures Inc., 85 F. Supp. 881 (S.D. N.Y. 1949). The Paramount case does not go so far as to declare this type of industrial structure illegal per se. The undesirable economic effects of the structure of the movie industry were greatly enhanced by the vertical and horizontal conspiracies found by the court. United States v. Paramount Pictures, Inc., 334 U.S. 131 (1948); $c f$. United States v. Columbia Steel Corp., 334 U.S. 495 (1948). But the industrial structure alone would have had a similar effect in hampering the entry into the industry of independent producers, since large sectors of the exhibition outlets would have been closed to them. See Rostow, The New Sherman Act, A Positive Instrument of Progress, 14 U. OF CHI. L. REv. 567, 569 (1947); McDonough \& Winslow, supra note 8.

See also the market analysis in United States v. Reading Co., 226 U.S. 324 (1912). There, control over rail transportation was utilized to control the market price for coal, and to exclude competitors from both the coal production and rail transport markets. Similarly examine United States v. Terminal Railroad Association of St. Louis, 224 U.S. 383 (1912), and Standard Oil Co. v. United States, 221 U.S. 1, 77 (1911).

38. For analysis of the effect of vertical integration on the exclusion of new entrants, see Hale, Vertical Integration: Impact of the Antitrust Laws Upon Combinations of Successive Stages of Production and Distribution, 49 CoL. L. Rev. 921, 947-8 (1949); Adelman, Effective Competition and The Antitrust Laws, 61 Harv. L. Rev. 1289, 1312 (1948); Frank, The Significance of Industrial Integration, 33 J. PoL. Econ. 179 (1925).

39. "Each of the three integrated producers has fabrication facilities with a capacity that is at least double that of their reduction establishments." United States v. Aluminum Co. of America, 91 F. Supp. 333, 372 (S.D. N.Y. 1950). And see note 31 supra.

No completely adequate explanation of the phenomenon of twice as much fabrication as ingot capacity is to be found in either the record or decision. It may well be due to the 
into ingot production is no easy matter. Ready access to bauxite ${ }^{40}$ and cheap electric power ${ }^{41}$ as well as a large supply of risk capital ${ }^{42}$ are all necessary. Thus requiring an ingot producer to raise twice as much capital

fact that excess diversified fabrication facilities enable an ingot producer to insure an outlet for ingot in times of price decline by shifting production to more stable lines. However, this does not necessarily mean that more ingot could be consumed, since the idle fabrication may be either wholly or partly in the later of successive stages of fabrication.

40. The problem a new competitor would face in securing bauxite is detailed in REPORT of the Surplus Property BoARd to Congress 31 (Sept. 21, 1945). There is also a suggestion as to how the Government might aid potential competitors by securing foreign bauxite supplies. Government aid in the form of a $\$ 12,000,000$ ECA loan to Great Britain for the development of Jamaican bauxite has already provided Reynolds with an independent source. Transcript of Record 160-2. Kaiser, on the other hand, is largely dependent on Alcoa for bauxite, Government Brief at 149-150. For a discussion of the possibility of development of substitutes, as well as an analysis of world bauxite supplies, see REPORT No. 14, WAR Changes in Industry series: Aluninuas 42-4, 51, 56 (prepared by the United States Tariff Commission 1946).

41. "Roughly ten kilowatt hours of electricity . . . are required to produce one pound of aluminum." United States v. Aluminum Co. of America, 91 F. Supp. 333, 348 (S.D. N.Y. 1950). A suggested modification of federal power contracts aimed at fostering new competition is set forth in REPORT No. 14, op. cit. supra note 40 at 91 . Such flexible power arrangements would result in lower electric costs per unit of output. For analysis of their effects, see REPORT OF THE SURPLUS PROPERTY BOARD TO CONGRESS 38 (Sept. 21, 1945).

42. The capital problem can be illustrated by estimating, on the basis of the original cost of government war-time facilities as set forth in Table No.I, United States v. Aluminum Co. of America, 91 F.Supp. 333, 351 (S.D. N.Y. 1950), how much capital would be necessary to set up a hypothetical integrated competitor about half the size of Kaiser. In 1948, Kaiser produced $256,289,000 \mathrm{lbs}$. of ingot, which was $20.6 \%$ of all ingot produced in the United States. Id. at 360 . The hypothetical integrated competitor, producing $10 \%$ of all ingot, or $124,392,000 \mathrm{lbs}$. annually, would need refining, reduction, and fabrication facilities:

The investment per lb. of alumina refining capacity, at the smallest war-time alumina plant, was $2.7 \mathrm{c}$. Two $\mathrm{lbs}$. of alumina are necessary to produce one $\mathrm{lb}$. of aluminum ingot, so that $248,784,000 \mathrm{lbs}$. of refining capacity costing approximately $\$ 6,717,168.00$ would be required for refining investment.

Investment per $\mathrm{lb}$. of reduction capacity at the Jones Mill, Arkansas, reduction plant, about the same size as the hypothetical producer, was $24.5 \mathrm{c}$. Thus with a projected ingot capacity of $124,392,000 \mathrm{lbs}$, about $\$ 30,380,040.00$ would be invested in reduction plants.

The more widely diversified the fabrication facilities owned by the new competitor, the better his chances of success. See note 33 supra and note 56 infra. But let us assume initial construction of only sheet and extrusion plant. The investment per lb. of capacity at the Spokane sheet plant was $16.4 \mathrm{c}$; and in the Grand Rapids extrusion plant, 6.7c. The experience of the industry has shown that a successful competitor would need twice as much fabrication as production capacity. Supplement to the Government's Brief 14. Assuming that the fabrication capacity of the hypothetical competitor is to be evenly divided between sheet and extrusion facilities, at least $\$ 28,734,552$ would have to be invested in fabrication plants.

Thus the hypothetical integrated competitor would need approximately $\$ 65,831,760$ of initial investment capital, almost half of which would go to build fabrication plants.

The experience of the Southern Aluminum Co. at the outbreak of World War I in trying to raise the $\$ 7,500,000$ needed to complete an aluminum plant, illustrates the financial prob- 
to build fabrication as well as ingot plants ${ }^{43}$ is a serious stumbling block in the path of new competitors.

Similarly a new fabricator would be at a severe competitive disadvantage without his own ingot production. ${ }^{44} \mathrm{He}$ must depend on either domestic integrated producers or foreign suppliers for ingot. The principal foreign source is the substantial production of Aluminium Limited of Canada. ${ }^{45}$ But the competitive effectiveness of even an unshackled Aluminium is likely to be limited by tariff vagaries, ${ }^{46}$ Aluminium's total dependence on foreign bauxite, ${ }^{47}$ narrowing differential in power costs, ${ }^{48}$ and the recent

lems involved in entering the industry. SEN. Doc. No. 67, 69th Cong., 1st Sess. 4-6 (1926). For an explanation of Henry Ford's failure in his attempt to enter the aluminum industry, see Londen \& Collins, The Aluminum Industry, 8 HARv. Bus. REv. 67, 76, (1929).

43. See note 42 supra.

44. "Explanation of the hesitancy of independent enterprise to enter this field must be found in a distaste for dependence upon monopoly for ingot supply, and the power of the integrated monopoly over the ingot-sheet price differential." WALlaCE, op. cit. supra note 30 , at 375 .

45. United States v. Aluminum Co. of America, 91 F.Supp. 333, 392-5 (S.D. N.Y. 1950). For summary of production by countries throughout the world, see TARIFF CosMISSTON REPORT No. 14, supra note 47, at 6.

46. The history of the effect of tariffs on the aluminum industry is summarized in TARIFF CoMMrssion REPORT No. 14, supra note 47, at 105-8. The downward trend in tariffs of recent years now shows signs of reversal. Press statement No. 18 of Rep. E. Celler (Dem. N.Y.), Chairman of the House Judiciary Committee, may be the forerunner of a re-emerging protectionist attitude toward the domestic aluminum industry. He said, on Oct. 23, 1950, that government stock-piling should be aimed at "utilization of the long term production potential of the domestic aluminum industry." See also statement by Secretary of Commerce Sawyer that aluminum stock-piles are to be built up primarily by expanding domestic production, Wall St. Journal, Oct. 23, 1950, p. 3, col. 1. Following this policy, the Government through the National Production Authority recently turned down "all, or part, of Canada's offer to sell up to $440,000,000$ pounds to the United States for its stockpile." This offer was refused in spite of the "35\% cut in civilian use which is expected." N.Y. Times, Nov. 5, 1950, § 3, p. 1, col. 8 .

The 1950 court's opinion as to Aluminium's competitive effectiveness was predicated on no rise in the tariff. United States v. Aluminum Co. of America, 91 F. Supp. 333, 394 (S.D. N.Y. 1950). With the present tariff, Aluminium's cost per lb. of ingot is 10.21c, while Alcoa's costs range in the area of $10.66 \mathrm{c}$ per $\mathrm{lb}$. $I d$. at 375 . Thus even a slight cost rise for Aluminium would seriously weaken its competitive strength in the United States market.

47. United States v. Aluminum Co. of America, 91 F. Supp. 333, 393 (S.D. N.Y. 1950), Part of Aluminium's reserves are concentrated in Africa, the rest in South America. For some idea of the bauxite transport difficulties that arose during the last war, see TARIFF COMMISSION REPORT No. 14, op. cit. supra note 37, at 61.

48. The three American producers pay about one-fifth of their total "mill cost per ingot ton" for electric power. United States v. Aluminum Co. of America, 91 F. Supp. 333, Table VII (S.D. N.Y. 1950). Alcoa's electric cost per unit output is about $10 \%$ lower than Reynolds and Kaiser. Id. at 375.

The differentials which now exist between American and Canadian power costs, due to cheap Canadian power supply, are being narrowed by such American federal power projects as the TVA, which now supplies one of Alcoa's biggest ingot production plants. See Troxel, Econosics of Public Utilities ch. 34 (1947). If the modification of federal power contracts referred to in note 41 supra were adopted, similar low cost advantages might be 
unpegging of the Canadian dollar. ${ }^{49}$ Thus independent fabricators would have to rely on Alcoa, Reynolds, or Kaiser for ingot. For the past three years, Alcoa has supplied an average of $85 \%$ of the ingot consumed by the independents. ${ }^{50}$ As the court pointed out, there is little reason to expect that Reynolds and Kaiser will attempt of their own volition to increase their relatively insignificantcontribution to the independent market. ${ }^{51}$ Both these companies have twice as much fabricating capacity as ingot production. ${ }^{52}$ They would therefore hesitate to increase their already heavy fixed cost of unused and undepreciated fabricating equipment by diverting ingot which would leave more fabricating machines idle. ${ }^{53}$ The only time Reynolds and Kaiser have attempted to increase their ingot sales to these "second-class" customers was during the 1949 break in the fabricated market ${ }^{54}$ - a break not likely to recur in the foreseeable future. The ardor of potential ingot competition is further dampened by the fact that Reynolds and Kaiser would benefit almost as much as Alcoa from the independent fabricators' being squeezed out. ${ }^{55}$

The probable ineffectiveness of competition-either from Reynolds and

extended to smaller producers. Furthermore, adoption of lower public power rates may be forthcoming when the federal government's projected $300 \%$ increase in the public power supply is completed sometime within the next ten years. See Power ProJEcr REsPoNSibilities of the Departaent of InTERror (Dep't of Interior, Oct. 1, 1950). For an estimate of the undeveloped public power potential in the United States, see Hearings, Senate Committee on Interior and Insular Affairs on A National Resources Policy, 81st Cong. 1st Sess. 245 (1949).

49. On September 30, 1950, the Canadian dollar was freed from the official exchange rate. For an analysis of the background and implications of this move, see CANADIAN Statistical Review IV-VIII (Oct. 1950). The price of an American dollar dropped from $\$ 1.10$ to $\$ 1.05$ in Canadian dollars. Id. at IV. Prior to Sept. 30, 1950, a Canadian manufacturer doing business in the United States could take each ten American dollars he received for his product back to Canada and get eleven Canadian dollars. After September 30, 1950, the same American ten dollars would bring him only $\$ 10.50$ in Canadian money. This currency move will make it more difficult for any Canadian producer to compete in the American market.

50. United States v. Aluminum Co. of America, 91 F. Supp. 333, Table III at 356 (S.D. N.Y. 1950). During the same three years, Reynolds supplied an average of about $11 \%$, and Kaiser an average of about $31 / 2 \%$. Ibid.

51. Ibid. A recent Government agreement with Kaiser, however, will require allocation of part of the production of a proposed new aluminum plant to "other," presumably independent, fabricators. N.Y. Times, January 26, 1951, p. 1, col. 4; p. 12, col. 4.

52. See note 39 supra.

53. Id. at 356. The Government maintained that "Reynolds and Kaiser had to emphasize fabrication . . . to keep their overhead costs at fabricating plants down." Government Brief 108.

54. With the first signs of a "buyer's market" in consumer's goods in 1949, Reynolds and Kaiser attempted to compete in this non-integrated market for ingot. United States v. Aluminum Co. of America, 91 F. Supp. 333, 356 (S.D. N.Y. 1950). For evidence of the difficulties they encountered as "intermittent sellers," see Transcript of Record, Govt. Exhibit 67, 81A, and p. 828, 1464.

55. These two producers would not benefit quite as much as Alcoa from the elimination of the independents. Reynolds' and Kaiser's only serious fabricating competition comes 
Kaiser or from Alted-may leave the non-integrated market to Alcoa by default. Independent fabricators are the only competitors Alcoa has in the field of kitchen utensils and other specialty items. ${ }^{56}$ Often in the past Alcoa has yielded to temptation; its dominant position as an ingot supplier has been used to hamper its non-integrated competitors selling fabricated goods. ${ }^{67}$ Alcoa still has the power to discriminate against these competitors today. ${ }^{58}$ And its power to do so will continue so long as it is integrated and so long as it remains the dominant supplier of the independent fabricators.

from Alcoa, see note 57 infra. Alcoa, on the other hand, in many fabricating fields has no competition besides the independents.

56. The fields in which Alcoa has only independent fabricating competition are shown by the following summary of the types of fabrication capacity possessed by each of the three integrated producers:

1948

Percentage of Each Company's Fabricating Capacity

\begin{tabular}{|c|c|c|c|}
\hline Sheet & $\begin{array}{c}\text { Alcoa } \\
\% \\
50\end{array}$ & $\begin{array}{c}\text { Reynolds } \\
\% \\
65\end{array}$ & $\begin{array}{c}\text { Kaiser } \\
\% \\
56\end{array}$ \\
\hline Extrusion and Tubing & 15 & 12 & \\
\hline Rods, Bars, Shapes, Wire, and Cable & 17 & 13 & 43 \\
\hline *Castings & 9 & & \\
\hline *Forgings & 4 & & \\
\hline Foil & 3 & 8 & 1 \\
\hline *Aluminum Utensils & $13 / 4$ & & \\
\hline \multirow[t]{2}{*}{ Powder and Paste } & $1 / 4$ & 2 & \\
\hline & 100 & 100 & 100 \\
\hline
\end{tabular}

See United States v. Aluminum Co. of America 91 F. Supp. 333, 372-4 (S.D. N.Y. 1950). In starred markets Alcoa has only non-integrated fabricating competition. It should be noted that fabrication is not always a one-stage process itself. The utensils above, for example, require a second stage of fabrication processing after the sheet manufacture.

57. Alcoa's restrictive practices are summarized, together with the attacks both private and governmental made on them, in Reuschlein, Aluminum and Monopoly: A Phase of an Unsolved Problem, 87 U. OF PA. L. REv. 509, 535-7, and n. 127 (1939). The process of restriction is further detailed in WALLACE, op. cit. supra note 30, at 367-408. He examines in particular the effect of Alcoa's retrictive practices on the aluminum cooking utensils industry. Id. at 408-442. Wallace concludes that the most effective means of securing competition in the fabricating field would be to exclude ingot producers from later stages of production. $I d$. at 487 . This view is supported by another industry-wide study which concluded that "in the long run, The Aluminum Co.'s fabricating subsidiaries can undersell competition only by working on the profit margin that the parent Company derives from the sale of ingots. For there is little reason for crediting Alcoa with fabricating costs signifcantly lower than its competitors." The Aluminum Company of America, Fortune (Sept. 1934) 46,102 et seq.

58. Alcoa has "that special power," in the non-integrated market, which accompanies "disproportionate integration." A concern is "disproportionately integrated . . . [when at one or more stages of production or distribution it acts as a supplier or customer for enterprises with which it is in competition at other stages." EDWARDs, op. cit. supra note 18 , at 98 . "The policy of the law should be to . . . prevent the vertically integrated enterprise from controlling so much of the total supply at any stage . . . that adequate alternatives are unavailable to independent exterprises operating at preceding or subsequent 
This industrial pattern of market domination supported by integration is far from unique. ${ }^{59}$ The courts have long realized that power in one market is illegal when its effect is to restrict competition in a related market. ${ }^{60}$ Agreements binding railroads to buy all Pullman cars from one company were outlawed as restricting entrance into the manufacturing field. ${ }^{11}$ Requirement contracts binding taxi operators, in only a few cities, to purchase cabs from one company were said to "effectively limit the outlets through which cabs may be sold." ${ }^{2}$ The major movie producer-distributors utilized

stages." Id. at 130. Cf. Adelman, Integration and Antitrust Policy, 63 HARv. L. Rev. 27 (1949). Somewhat belated recognition of this problem by the Government is indicated by Article VII of its contract with Kaiser, dated Feb. 2, 1951. There it is required that $25 \%$ of "Kaiser's additional ingot production" be sold to independents.

59. The growth of vertical integration is analyzed in FTC, THE PRESENT TREND of CORPORATE MERGERS AND ACQUISITIONS 12 (1947). The FTC figures suggest that 17\% of postWorld War II mergers resulted in vertically integrated concerns. Id. at 11 .

60. An early judicial skirmish with vertical integration occurred in United States v. American Tobacco Co., 221 U.S. 106 (1911). Tin foil producers and suppliers of licorice for plug flavoring were divested because their acquisition was part of the attempt to monopolize tobacco production. Id. at 130. See Hale, supra note 38, at 923-4. See also United States v. Corn Products Refining Company, 234 Fed. 964 (S.D. N.Y. 1916) (divestiture of a candy factory bought by defendant syrup makers to force-under threat of competition -other candy producers to buy syrup from them). $C f$. United States v. International Harvester Company, 214 Fed. 987 (D. Minn. 1914), appeal dismissed, 284 U.S. 587 (1918); United States v. Eastman Kodak Co., 226 Fed. 62 (W.D. N.Y. 1915).

Vertical integration got what looked like the stamp of official approval as a "facility of industrial progress" in United States v. United States Steel Corp., 251 U.S. 417, 442 (1920). But despite this seeming approbation, integration in some areas received less favorable treatment. See Crescent Cotton Oil Co. v. Mississippi, 257 U.S. 129 (1921) (upholding a state statute making it illegal for a manufacturer of cotton seed oil to operate a cotton gin). The "commodities clause" forbade railroads to transport "any article or commodity ... manufactured, mined, or produced by them, ... or which they own in whole or in part . . "24 Stat. 379 (1887), as amended, 34 Stat. 584 (1906), 49 U.S.C. $\S 489$ (1946). But see, United States v. South Buffalo Ry. Co., 333 U.S. 771 (1948); United States v. Elgin, J. \& E. R. Co., 298 U.S. 492 (1936) (use of a holding company to circumvent commodities clause upheld). The airlines have been similarly treated, 52 STAT. 1001 (1938), 49 U.S.C. $\S 489$ (1946).

The influence of the Steel case has declined sharply in the past twenty years. Vertical integration was successfully attacked in the meat-packing industry in United States v. Swift and Co., 286 U.S. 106, 117 (1932). In the 1940's renewed attacks were launched against vertical integration in various sectors of the nation's industry. See United States v. Klearflax Linen Looms, Inc., 63 F. Supp. 32 (D. Minn. 1945); United States v. General Motors Corp., 121 F.2d 376 (7th Cir. 1941); notes 61-4 infra.

61. United States v. Pullman Co., 50 F. Supp. 123 (E.D. Pa. 1943). But $c f$. United States v. Pullman Co. et al., 64 F. Supp. 108 (E.D. Pa. 1945).

62. United States v. Yellow Cab Co., 332 U.S. 218, 226 (1947). Cf. United States v. Yellow Cab Co., 338 U.S. 338, 339 (1949). For a similar situation, see United States v. International Salt Co., 332 U.S. 392, 396 (1947). See Note, 57 YALE L.J. 1298 (1948). Market control violative of the Sherman Act is equally illegal whether maintained by exclusive sale contracts and undue exercise of patent privileges or direct ownership through integration. 
ownership over first-run exhibition outlets to restrain competition on the exhibition level..$^{63}$ This ownership was held to constitute in that context a violation of Section 2 of the Sherman Act, requiring complete divestiture. ${ }^{64}$ In aluminum, integration excludes competitors from the ingot field ${ }^{65}$ and makes independent fabricatorsdependent on their principal competitor, Alcoa, for ingot. Separation would encourage new entrants into both markets.

But this court entered the ring with its hands partially tied. This proceeding was the remedial sequel to Alcoa's 1945 conviction; since Reynolds and Kaiser were not sued as violators, they were not now before the court. ${ }^{66}$ Thus the court faced the task of establishing effective competition in aluminum, while having jurisdiction over only half the industry. This task was made doubly difficult by Government surplus disposal which set up Reynolds and Kaiser with integrated ingot and production facilities.

Nevertheless the court was not so helpless as it appeared to be; it could have separated Alcoa's fabricating plants from its ingot production. This one move would have greatly increased the sales outlets open to any potential ingot producer. ${ }^{67}$ It would also eliminate competition by sufferance in the fabricated market. New fabricators would no longer be dependent on their strongest competitor for their ingot supply. ${ }^{68}$

Separation of Alcoa's ingot production from its fabrication plants would minimize Alcoa's incentive not to sell ingot to independent fabricators. ${ }^{69}$ But barring a radical change in Aluminium's position and policies, Alcoa would still be the only effective ingot supplier to this non-integrated market. Alcoa's control over ingot price in the independent market would be as

63. United States v. Paramount Pictures, 334 U.S. 131, 166-9 (1948).

"Entry into the [producing] industry will be impossibly handicapped and not really competitive so long as the existing majors continue to own or to control access to the best theatres." Rostow, supra note 37, at 599. See also Evans, Bertrand \& Blanchard, THE Motion Picture Industry-A Pattern of Control 5, 13, 55 (TNEC Monograph 43, 1941); Note, Enforced Independence for Motion Picture Exhibitors, 48 YALE L.J. 339, 345 (1938).

64. Ibid.; United States v. Paramount Pictures, 85 F. Supp. 881, 893 (S.D. N.Y. 1949).

65. See pages 301-303 supra.

66. Reynolds and Kaiser became factors in aluminum production only after they bought the government surplus plants after 1945. For a brief summary of the history of both companies in the industry, see Brief of the Aluminum Co. of America 16-22.

67. For the past three years, the independent fabricators have consumed an average of $218,000,000 \mathrm{lbs}$. of ingot annually. See note $31 \mathrm{supra}$. This is the only market in which a new ingot producer could presently compete. Alcoa's fabricating facilities, even though half of them are idle, consume 700,000,000 lbs. annually. By untying Alcoa's ingot plants from fabrication units, sales outlets presently consuming over $900,000,000$ lbs. of ingot would be made available, for which Alcoa and any new producer might compete. Thus a new producer would have available to him potential sales outlets over four times as great as at present. See, however, notes 51 and 58 supra.

68. See note 57 supra.

69. Alcoa no longer would stand to gain an estimated $\$ 5,000,000$ per year by selling to their own rather than independent fabricators. See note 32 supra. 
complete as it is presently. ${ }^{70}$ This control over price, a traditional earmark of monopoly power, ${ }^{71}$ could be weakened by reducing Alcoa's size in the ingot market. ${ }^{72}$ Dissolution of Alcoa's ingot capacity into two competing units would be the first move. ${ }^{73}$

As the court predicted, increasing military need for aluminum will require expansion of productive capacity. ${ }^{74}$ Judicial analysis might have guided emergency expansion as it did surplus disposal. ${ }^{75}$

"Effective competition" at the ingot level would not emerge full blown from mere dissolution of Alcoa into two producing units. One more ingot producer would hardly change the basic market structure of oliogopoly..$^{76}$ The Government should stimulate new ingot capacity either by loaning money to new independent producers, or by building new plants and disposing of them to independents after the emergency. This would intro-

70. This market situation was described at the trial as competition "confined to rivalry for orders." Transcript of Record 1443.

71. Sugar Institute Inc. et al. v. United States, 297 U.S. 553,601 (1936); United States v. Trenton Potteries Inc., 273 U.S. 392, 396-7 (1927). See also United States v. General Electric Co., 80 F. Supp. 989, 1015 (1948): "the total absence of price competition . . . [is a] sure [sign] of monopoly control ...."

72. "Size of business units is the outstanding cause of departure from competition. The first change required would be therefore a reduction in the size and an increase in the number of firms." BURNS, THE DECLINE of CoMrPETrTION 525 (1936). For further analysis of the relation between size in a market and monopoly power, see Rostow, The New Sherman Act; A Positive Insirument of Progress, 14 U. OF CHI. L. REv. 567, 589 (1947). Judicial expression of the significance of size as an earmark of monopoly power is found in United States v. Aluminum Co. of America, 148 F.2d 416 (2d Cir. 1945); United States v. Griffith, 334 U.S. 100,107 , n.10 (1948).

Alcoa's size in the market can be gauged by the standard of total assets. As of Dec. 31,1948 , Alcoa's assets were $41 / 2$ times those of Reynolds, and nearly $101 / 2$ times those of Kaiser. Brief of the United States, Table 11 at 145. "Alcoa's asset position [comprising] $76 \%$ of the total assets of the aluminum industry, far exceeds the positions held by the largest companies in the copper and steel industries." Id. at 146.

73. No more than two competitors could be set up because Alcoa presently owns only two alumina plants. See United States v. Aluminum Co. of America, 91 F. Supp. 333, 368 (S.D. N.Y. 1950). The Government plan contemplated compensating for the efficiency discrepancy between these two plants by combining high cost reduction with low cost alumina plants and vice versa.

Alcoa is now planning a new plant, to be located near Bauxite, Arkansas. Wall St. Journal, January 22, 1951, p. 4, col. 2.

74. See statement issued by National Securities Resources Board, reprinted in Wall St. Journal, Oct. 24, 1950, p. 2, col. 2, to the effect that reduction capacity is to be more than doubled within the next 18 months. "Specifically under scrutiny were tentative plans for increasing capacity of the existing firms." Id. col. 2.

75. United States v. Aluminum Co. of America, 148 F.2d 416, 446 (2d Cir. 1945). See also Roback, Monopoly or Competition Through Surplus Plant Disposal? The Aluminum Case, 31 CoRN. L.Q. 302, 313-4 (1946) for analysis of the effect on surplus disposal of the 1945 court's mandate.

76. Oligopoly has been defined as that market condition "when there are just a few rival sellers, [and] each seller takes into account the ways in which his rivals may respond to any price policy he may pursue." Bowman \& Bach, Economic ANalysis and Public PoLICY, 303 (1946). 
duce a substantial number of new competitors to the ingot field. Moreover these new competitors need not be evanescent war-time phenomena; competitive prices could tap the peacetime markets necessary to sustain this production jump."7

The court's inability to disintegrate Reynolds and Kaiser could be remedied by a Government policy of no further aid for expansion of these integrated units. ${ }^{78}$ Thus a diminishing share of production and fabrication would be tied together through integration.

This suggested competitive structure, involving separation of fabricators from ingot producers and ingot production by a greater number of smaller plants, would result in no loss of technological efficiency. Fabricating costs of the nonintegrated fabricators are no higher than those of the integrated fabricators. ${ }^{79}$ And in regard to ingot production, the seductive equation of plant size with economy of unit cost is disproved by comparison of ingot cost figures. Costs per ingot ton bear no relation to the size of the three producers' reduction plants. ${ }^{80}$ Any disadvantages of smaller research units

77. The results of a survey conducted by the University of Washington in cooperation with the Department of Interior, reported in Report of THE SURPLus Property BoARD To CoNGRess 39-40 (Sept. 21, 1945), indicate that lower prices could tap a potential aluminum market of almost double present capacity. It has been argued that dislikefor reliance on one company for supply, as well as the failure of price to respond to changes in cost and demand, Brief of the United States at 96, has curbed increased use of aluminum. WALLACE, op. cit. supra note 30, at 374-5. See also Note, The Aluminum Industry: An Anti-Trust Experience, 37 CoL. L. REv. 269, nn. 113-4 (1937).

78. Details of proposed low-interest loans and government subsidies to speed emergency aluminum expansion are discussed in Wall St. Journal, Nov. 21, 1950, p. 7, col. 1, and Nov. 22,1950, p. 2, col. 2. See note 51 supra.

79. See The Aluminum Company of America, Fortune (Sept., 1934) 46, 102 et seq.; and comparison of the costs of operating war-built fabrication plants, now operated by Reynolds and Kaiser, with plants of independent fabricators, in REPORT OF THE SURPLUS PROPERTY BoARD to Congress 59-74 (Sept. 21, 1945). Wallace agrees, by inference, that no substantial cost differential prevails when he concludes that independent fabricators-if assured of ingot-can continue to compete successfully with the integrated concerns. WaLLACE, op. cit. supra note 30 , at 485 .

Vertical integration has been termed a "catching fever"; if one enterprise engages in it, its rivals are compelled to do so likewise. Hale, supra note 38, at 937 . For analysis of the higher costs of production resulting from such compulsory integration, see CHALrBERLIN, The Theory of Monorolistic Competition 123 (1938); Miller, UnFair Competition 213 (1941). These cost increases have been detailed in specific industries. "Less integrated companies had a better record of efficiency in the farm machines industry, the automobile industry, and the steel industry than larger and more highly integrated companies." RELAtive EFficiency of LaRge, MEdidm-Sized and SMall Business 93 (TNEC Monograph 13, 1941). On the basis of recent FTC studies of unit cost data in the baking, rubber tire, and fertilizer industries, one expert concludes that "at the very least, the widely held assumption that the ownership and control of plural production units by single corporate enterprise units contributes to efficiency would seem to rest upon an overwhelming absence of supporting facts." Blair, Technology and Size, 38 AM. Econ. Rev. 121, 126 (1948).

80. See Report of the Surplus Property Board to the Congress (Sept. 21, 1945). Compare Appendix 13(c) at 93, Annual Capacity of Reduction Planls, with Appendix 15(c) at 117, Representative Costs and Possible Post-War Production Costs at the Mill of Pig Alum- 
might be surmounted by industry-supported research, as in the oil industry, or by independent research firms. ${ }^{81}$

The consumer would benefit substantially from separation and dissolution. Competitive ingot prices would encourage the development of new uses for aluminum. ${ }^{82}$ Also lower transport costs would be made possible by separation of ingot production from fabrication. Fabrication plants nearest ingot supplies and consumer markets could be fully utilized. Such optimum use is precluded now because. fabricators closest to one ingot producer sometimes belong to another integrated producer located further away. ${ }^{83}$

Failure to analyze the effects of vertical integration thus dims the hope for effective competition in aluminum. This court did less than it might have; but even if it had done what the Government requested and created a new vertically integrated competitor, new entry would still be virtually impossible.

On the other hand, the court's new remedial test adds a potentially useful weapon to the antitrust arsenal. By emphasizing the prevention of future dominance-rather than the destruction of present monopoly-the court in effect divorced the remedy from the violation. Future courts may apply this remedial standard to reshape entire industries and thus avoid the now familiar antitrust cycle of one violation springing from the roots of another just condemned.

inum. These plants were all built at about the same time, and there is no correlation between size and efficiency.

81. See Rostow, A National Policy for the Oll IndUstry 14, 67-8, 142-3 (1948). See also Universal Oil Products Co. v. Campbell, 181 F.2d 451 (7th Cir. 1950) (research firm organized and supported by five largest oil producers). For arguments in favor of nationally financed industrial research, see Hearings Before the Committee on Interstate and Foreign Commerce on H.R. 6446, 79th Cong., 2d Sess. 65-94.(1946). There is no necessary correlation between size of firm or size of research expenditure and success in discovery. See Hertz \& Rubinstein, How Industrial Firms Handle Research; Practices among FortyOne Industrials, 57 CheMr. ENg. 111 (Aug., 1950); Clamer, Research From the Standpoint of the Smaller Business Enterprise, 249 FrankLIN INST. J. 367-91 (May, 1950). See also Schlaifer, Big Business and Small Business; A Case Siudy, 38 Harv. Bus. Rev. 4, 97 (1950).

82. Under the shadow of the antitrust proceeding, post-war aluminum prices have been kept low while other prices have risen. Competition might result in a short run price rise above these artificial post-war levels. On the other hand, prices reflecting the pressures of demand should attract more privately financed capacity and in the long run eliminate the chronic shortages resulting from artificially maintained low prices and non-expansion. See note 77 supra.

83. Reynolds owns reduction plants located in Alabama, Arkansas, Oregon, and the State of Washington. Most of its fabrication capacity, on the other hand, is located in Illinois and Michigan. Thus ingot must be shipped a considerable distance from one of Reynolds' ingot plants to its fabrication facilities. Alcoa has reduction plants located in Tennessee, North Carolina, New York, and Texas, while its fabrication facilities are scattered through Tennessee, New Jersey, Indiana, Pennsylvania, California, Connecticut, Michigan, and Ohio. If all producers were separated from fabrication facilities, then considerable economy might result from Reynolds' ingot plants on either coast being able to utilize Alcoa's nearby fabrication plants. See United States v. Aluminum Company of America, 91 F. Supp. 333, 365-374 (S.D. N.Y. 1950). For maps showing location of each producer's fabrication and production facilities, see FIRST BOSTON CORP., ALUMINUM 39-41 (1951). 